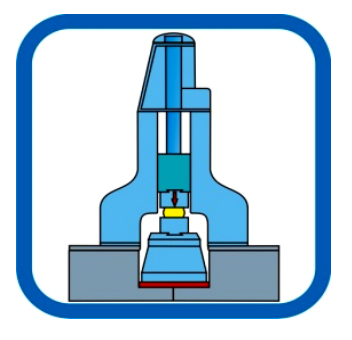

УДК 62-185

\section{РАЗДЕЛ IV \\ ОБОРУДОВАНИЕ И ОСНАСТКА ОБРАБОТКИ ДАВЛЕНИЕМ}

DOI: $10.37142 / 2076-2151 / 2020-1(50) 272$

Карнаух С. Г.

\title{
ДОСЛІДЖЕННЯ ЕНЕРГОСИЛОВИХ ХАРАКТЕРИСТИК ОБЛАДНАННЯ З ГІДРОПРУЖНИМ ПРИВОДОМ
}

У сучасних умовах розвитку економіки України актуальним залишається питання своєчасного відновлення парку устаткування для більшості виробництв. Особливо ця проблема актуальна для малих виробничих підприємств, які, внаслідок нестачі обігових коштів, не можуть собі дозволити придбання дорогого обладнання, а саме, типового імпортного обладнання з високим рівнем автоматизації [1-5].

Для рішення даної проблеми, для малих виробництв, розробляється оригінальне обладнання $з$ доступною вартістю й широкими технологічними можливостями. До такого обладнання (в галузі обробки металів тиском) відносяться високошвидкісні молоти і прес-молоти з гідропружним приводом конструкції Донбаської державної машинобудівної академії (ДДМА). Авторство цих розробок належить д-ру техн. наук, професору Роганов Л. Л. [6].

Основною особливістю гідропружного привода є використання, для розгону рухомих частин, енергії пружної деформації стислої рідини й пружно деформованих деталей ковальсько-пресового обладнання.

Для такого обладнання важливо знати його основні характеристики при реалізації різних технологічних операцій. До основних характеристик гідропружних приводів відносять: енергію удару, максимальну швидкість, максимальне прискорення рухомих частин, форму ударного імпульсу зміни прискорення в часі, час впливу ударного прискорення [6].

Як правило, ці параметри контролюються й записуються на осцилографі за допомогою сигналу від п’єзодатчика, пропущеного через підсилювач. При цьому помилка в записі величини того або іншого параметра буде складатися з помилок у ланках ланцюга датчика, підсилювача й накладення сигналів високочастотних коливань в електричних ланцюгах осцилографа. Тому ймовірність похибок записаних параметрів, як критеріїв оцінки вихідних енергетичних характеристик високошвидкісних машин, підвищується. Традиційні способи виміру пов'язані з необхідністю застосування складної контрольно-вимірювальної апаратури, наявністю навичок роботи з нею, проведенням експериментів у лабораторних умовах, більшим обсягом перерахувань. Це обмежує їхнє використання у виробництві [7-10].

Особливо важливо знати енергію удару та максимальну швидкість для здійснення технологічної операції, наприклад, при реалізації розділення сортового прокату на мірні заготовки. Досвід розробки й випробувань високошвидкісних машин на базі гідропружного привода, який є на кафедрі основ проектування машин ДДМА, дозволяє обгрунтувати більш прості й надійні методи оцінки енергетичних характеристик гідроприводу.

Мета роботи - розробка простих і надійних способів оцінки енергетичних характеристик гідроприводу високошвидкісних машин.

Контроль і регулювання швидкості переміщення рухомих частин машин ударної дії $\epsilon$ найважливішим чинником забезпечення якості продукції й підвищення продуктивності праці. Основною класифікаційною ознакою засобів контролю швидкості рухомих частин можна вважати конструкцію датчика, що фіксує переміщення або швидкість руху. За прин- 
ципом дії датчики можна підрозділити на групи: фотоелектричні (інфрачервоні) датчики швидкості й переміщення; індуктивно-частотні датчики швидкості й переміщення; кутові потенціометричні датчики переміщення; магнітоелектричні лінійні датчики швидкості; магнітоелектричні кутові датчики швидкості; тахогенераторні датчики швидкості; електро- і мілісекундні (у тому числі з використанням електросекундоміра) датчики; ємнісні датчики переміщення й швидкості; ультразвукові датчики швидкості; реохордні датчики переміщення; механічні датчики швидкості [7-9].

На практиці важливо знати максимальну швидкість рухомих частин високошвидкісних машин та величину енергії удару. Розробка нового способу виміру максимальної швидкості рухомих частин високошвидкісних машин та енергії удару дозволить використовувати нестандартне оригінальне встаткування ударної дії більш ефективно, з меншими витратами засобів і часу.

Для досягнення поставленої мети на кафедрі основ проектування машин (ОПМ) у ДДМА розроблений спосіб виміру максимальної швидкості, сутність якого полягає в тому, що втрати енергії у високошвидкісній машині оцінюються по деформації вимірювальної пружини, що імітує реальний опір деформуванню.

На рис. 1 показана схема виміру максимальної швидкості рухомих частин високошвидкісної машини - прес-молота (конструкції ДДМА) [11].

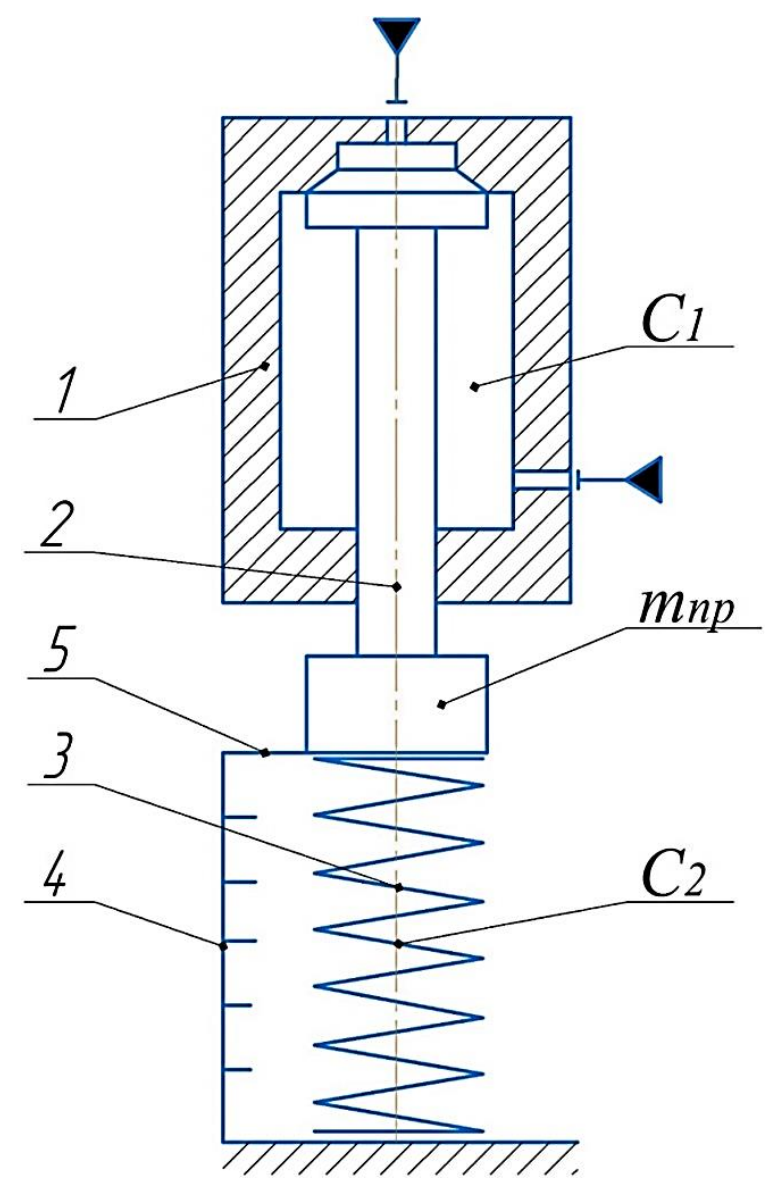

Рис. 1. Схема виміру максимальної швидкості рухомих частин прес-молота [11]

До складу комплекту вимірювання входять: досліджуваний об'єкт - гідропружний циліндр прес-молота 1 зі штоком і бойком 2, тарована пружина 3 і вимірювальна лінійка 4. Деформацію пружини заміряли по довжині риски на пластиліні, яку залишав стрижень 5, прикріплений до штока прес-молота. У свою чергу пластилін кріпився на спеціальній оправці до станини прес-молота. 
Розглянемо вивід рівнянь динаміки прес-молота.

1. Рівняння руху рухомих частин високошвидкісної машини з урахуванням сили опору з боку пружини, що імітує опір деформуванню, записували у вигляді (див. рис. 1):

$$
m_{\text {пр }} \cdot \ddot{\bar{x}}=\left(\Delta p \cdot A-C_{1} \cdot \bar{x}\right)-C_{2} \cdot \bar{x},
$$

де $m_{\text {пр }}$ - приведена маса рухомих частин прес-молота;

$\Delta p$ - робочий тиск у гідропружному циліндрі прес-молота;

$A$ - площа поперечного перерізу штока;

$C_{1}$ - жорсткість гідравлічної пружини, виконаної у вигляді гідропружного циліндра з акумуляторами;

$C_{2}$ - жорсткість пружини розтягання-стиску.

У результаті розв'язку рівняння (1) щодо швидкості, маємо:

$$
\dot{\bar{x}}=\sqrt{2 / m_{\text {пр }} \cdot\left(\Delta p \cdot A \cdot \bar{x}-\left(\left(C_{1}+C_{2}\right) / 2\right) \cdot \bar{x}^{2}\right)} .
$$

Максимальне значення швидкості $\dot{\bar{x}}_{\max }$ відповідає граничному значенню переміщення рухомих частин прес-молота $\bar{x}_{\text {пред }}$, яке визначалося з умови:

$$
\begin{gathered}
f^{\prime}(x)=0 ; \\
\left(2 / m_{\text {пр }} \cdot\left(\Delta p \cdot A \cdot \bar{x}-\left(\left(C_{1}+C_{2}\right) / 2\right) \cdot \bar{x}^{2}\right)\right)^{\prime}=0 ; \\
\bar{x}_{\text {пред }}=\Delta p \cdot A /\left(C_{1}+C_{2}\right) .
\end{gathered}
$$

Підставляючи (3) в (2), маємо:

$$
\dot{\bar{x}}_{\max }=\sqrt{(\Delta p \cdot A)^{2} /\left(m_{\text {пр }} \cdot\left(C_{1}+C_{2}\right)\right)} .
$$

2. Розглядали рівняння руху рухомих частин прес-молота при роботі в режимі холостого ходу без урахування опору пружини:

$$
m \cdot \ddot{x}=\Delta p \cdot A-C_{1} \cdot x
$$

де $m$ - маса рухомих частин прес-молота.

Тоді, аналогічно розглянутому вище, максимальну швидкість рухомих частин пресмолоту визначали з рівняння:

$$
\dot{x}_{\max }=\sqrt{(\Delta p \cdot A)^{2} /\left(C_{1} \cdot m\right)} .
$$

3. Співвідношення кінетичних енергій руху рухомих частин машини в робочому режимі й у режимі холостого ходу без обліку опору пружини записували у вигляді:

$$
W / \bar{W}=\left(m \cdot \dot{x}_{\max }{ }^{2} / 2\right) /\left(m_{\text {пр }} \cdot \dot{\bar{x}}_{\max }{ }^{2} / 2\right)=\left((\Delta p \cdot A)^{2} / C_{1}\right) /\left((\Delta p \cdot A)^{2} /\left(C_{1}+C_{2}\right)\right) \text {. }
$$

Звідки 


$$
\dot{x}_{\max }=\sqrt{m_{\text {пр }} \cdot\left(C_{1}+C_{2}\right) /\left(C_{1} \cdot m\right)} \dot{\bar{x}}_{\max } .
$$

Тоді рівняння (6) можна представити у вигляді:

$$
\dot{\bar{x}}_{\text {max }}=\sqrt{\left(\Delta p \cdot A /\left(C_{1}+C_{2}\right)\right)^{2}} \cdot \sqrt{\left(C_{1}+C_{2}\right) / m_{\text {пр }}}
$$

3 урахуванням того, що $\bar{x}_{\text {пред }}=\Delta p \cdot A /\left(C_{1}+C_{2}\right)$, рівняння (9) прийме вигляд:

$$
\dot{\bar{x}}_{\max }=\bar{x}_{\text {пред }} \cdot \sqrt{\left(C_{1}+C_{2}\right) / m_{\text {пр }}}
$$

4. Тоді рівняння (2) може бути перетворене у рівняння:

$$
1 / 2 \cdot m_{\text {пр }} \cdot \dot{\bar{x}}=-\left(\left(C_{1}+C_{2}\right) / 2\right) \cdot\left(\bar{x}-\Delta p \cdot A /\left(C_{1}+C_{2}\right)\right)^{2}+(\Delta p \cdot A)^{2} / 2 \cdot\left(C_{1}+C_{2}\right) \text {. }
$$

Звідки:

$$
\dot{\bar{x}}^{2} /\left((\Delta p \cdot A)^{2} /\left(C_{1}+C_{2}\right) \cdot m_{\text {пр }}\right)+\left(\bar{x}-(\Delta p \cdot A) /\left(C_{1}+C_{2}\right)\right)^{2} /\left((\Delta p \cdot A) /\left(C_{1}+C_{2}\right)\right)^{2}
$$

Залежність (12) - це рівняння еліпса. Аналіз рівняння показує, що:

$$
\bar{x}_{\text {пред }}=1 / 2 \cdot \bar{x}_{\text {екс }},
$$

де $\bar{x}_{\text {екс }}-$ максимальний хід рухомих частин прес-молота, що відповідає кінцевій деформації пружини. у вигляді:

Тоді рівняння (10) максимальної швидкості рухомих частин прес-молота записували

$$
\dot{\bar{x}}_{\max }=1 / 2 \cdot \bar{x}_{\text {екс }} \cdot \sqrt{\left(C_{1}+C_{2}\right) / m_{\text {пр }}} \text {. }
$$

Підставляючи (14) в (8), одержували рівняння для розрахунків максимальної швидкості рухомих частин прес-молота з урахуванням втрат енергії на тертя, дроселювання робочої рідини, пружну деформацію станини й привода:

$$
\dot{x}_{\max }=V_{\text {max }}=1 / 2 \cdot\left(C_{1}+C_{2}\right) \cdot \bar{x}_{\text {екс }} \cdot \sqrt{\left(C_{1}+C_{2}\right) / m} .
$$

Для практичної перевірки отриманої математичної моделі досліджувався прес-молот конструкції ДДМА. В експерименті використовувалися різні маси рухомих частин пресмолота: 6,25 кг, 9,34 кг. Параметри вимірювальної тарованої пружини: жорсткість -

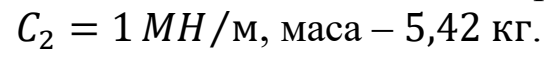

Дані розрахунків теоретичних і виміряних максимальних швидкостей рухомих частин прес-молота представлені у вигляді графіків $V_{\max }=f(\Delta p)$ (рис. 2-4) [11].

На основі аналізу графіків $V_{\max }=f(\Delta p)$ можна зробити наступні виводи. 


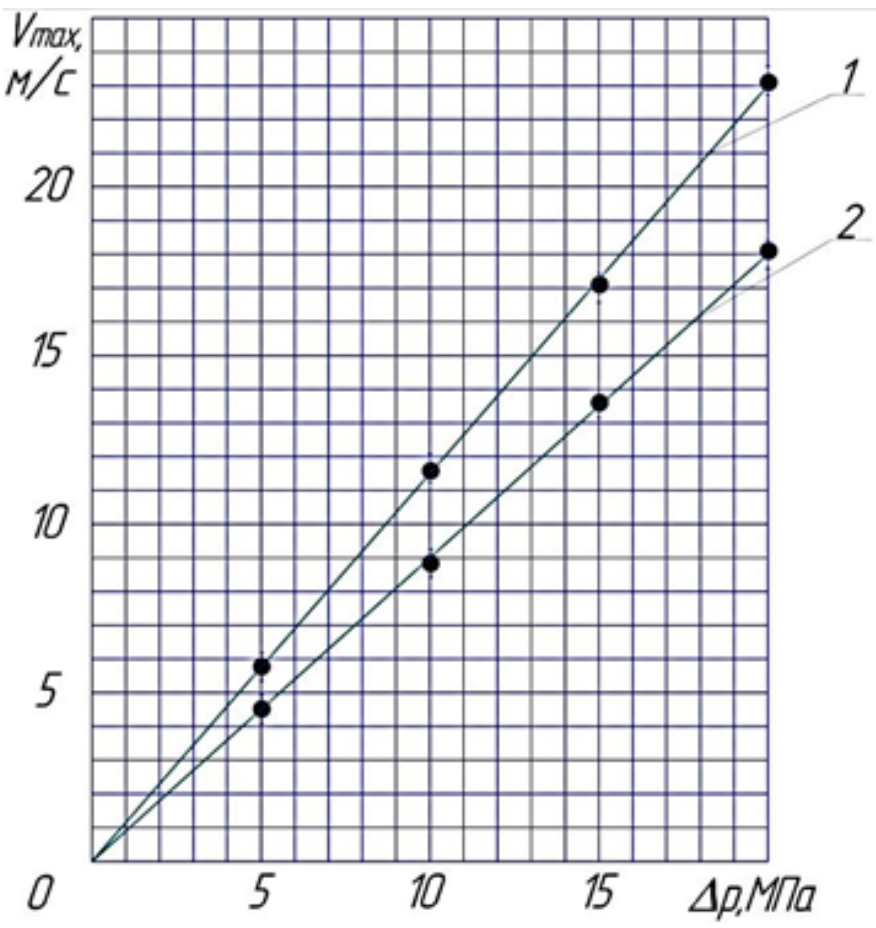

Рис. 2. Графік $V_{\max }=f(\Delta p)$ для $m=6,25 \kappa г: 1$ - теоретична максимальна швидкість, розрахована за формулою $V_{\max }=\sqrt{2 \cdot W / m}$, де $W$ - енергія, яка запасається у гідропружному циліндрі, гідросистемі й станині прес-молота; 2 - вимірювана максимальна швидкість [11]

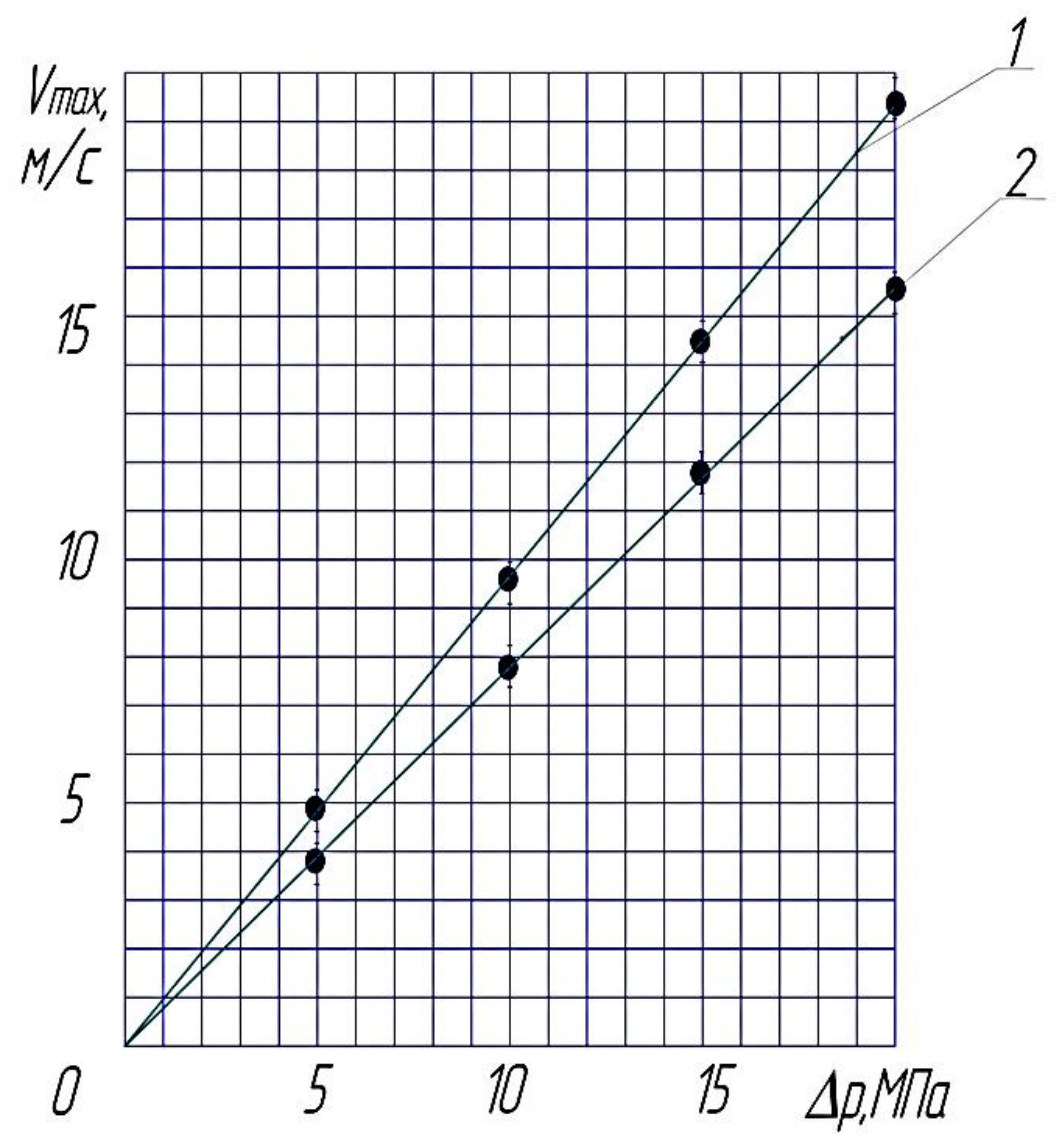

Рис. 3. Графік $V_{\max }=f(\Delta p)$ для $m=9,34 \kappa г: ~ 1-$ теоретична максимальна швидкість, розрахована за формулою $V_{\max }=\sqrt{2 \cdot W / m}$, де $W$ - енергія, що запасається у гідропружному циліндрі, гідросистемі й станині прес-молота; 2 - вимірювана максимальна швидкість [11] 


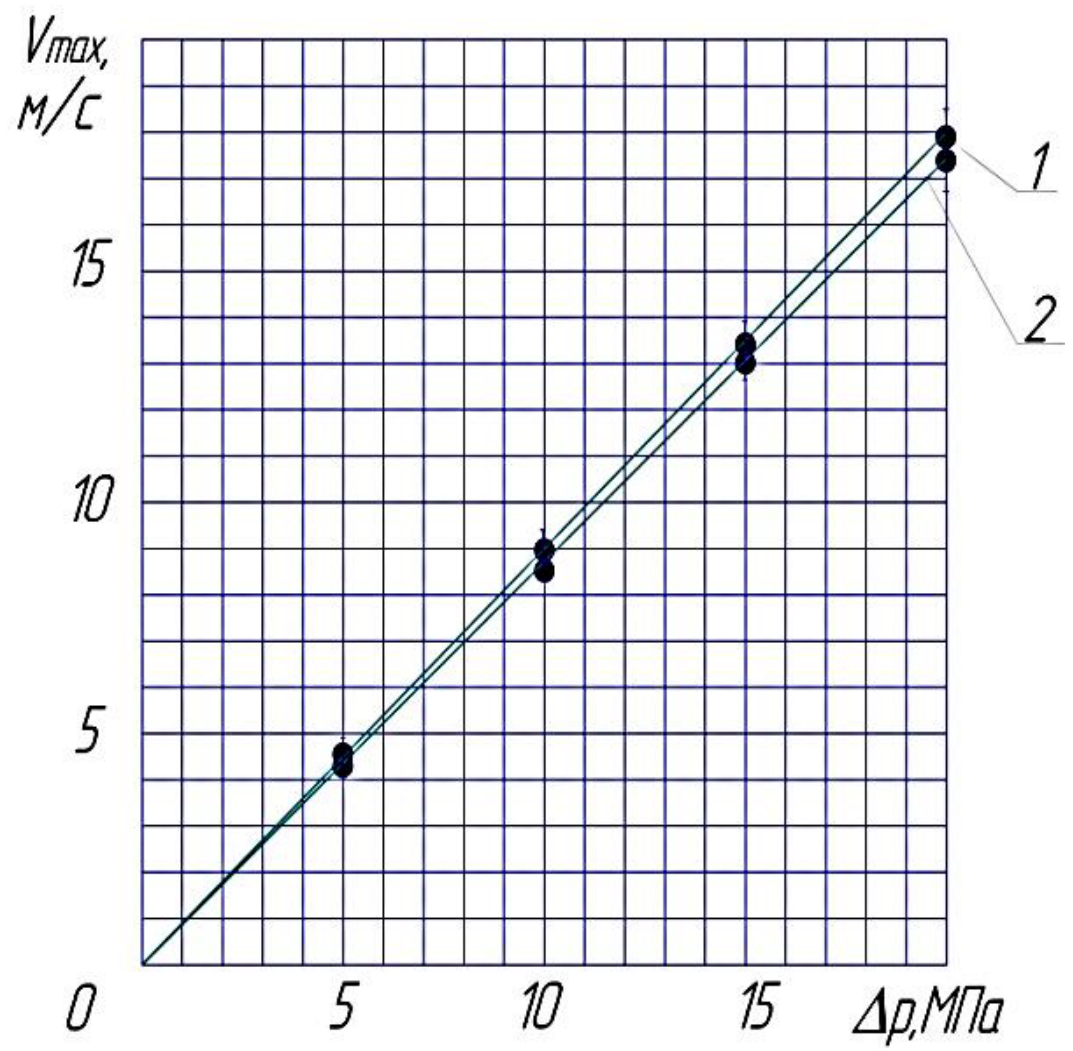

Рис. 4. Графік $V_{\max }=f(\Delta p)$ для $m=6,25 \kappa г: ~ 1-$ максимальна швидкість, вимірювана за допомогою запропонованого способу; 2 - максимальна швидкість, вимірювана 3 використанням відомого способу [11]

1. Розбіжність значень теоретичної й вимірюваної максимальних швидкостей становить у середньому $18 \%$ (рис. 2,3). Втрати швидкості рухомих частин прес-молота пов'язані більшою мірою із втратами на тертя штока в ущільненнях, дроселювання робочої рідини, а також із втратами енергії на розкриття імпульсного клапана гідропружного циліндра в момент формування переднього фронту ударної хвилі.

2. Запропонована математична модель розрахунків максимальної швидкості рухомих частин високошвидкісної машини забезпечує одержання достовірних даних, що підтверджується експериментами, проведеними за відомою методикою (рис. 4) [11]. Крива 2 практично збігається із кривою 1, яку побудовано для маси рухомих частин прес-молота $m=6,25 \kappa г$.

3. Значення корисної енергії руху рухомих частин прес-молота масами $m=6,25$ кг й $m=9,34$ кг відрізняються в середньому на $10 \%$. Це пов'язане з погрішністю виміру максимальних швидкостей, яка становить у середньому $5 \%$.

На відміну від відомих способів виміру швидкості рухомих частин високошвидкісних машин, запропонований спосіб простий у реалізації, не вимагає наявності складного вимірювального встаткування, на погрішність експерименту не впливають реальні умови ковальсько-пресового виробництва, зменшується час проведення експерименту й обсяг перерахувань.

Таким чином, запропонований спосіб виміру максимальної швидкості рухливих частин може бути рекомендований для впровадження на виробництві при дослідженні можливостей високошвидкісних машин і розробці пов'язаних з ними технологічних процесів.

Величину енергії удару, яка накопичується у гідропружному циліндрі високошвидкісної машини, можна досить точно виміряти, використовуючи спосіб «підскоку кульки», без застосування складного контрольно-вимірювального устаткування.

Схема виміру енергії удару способом «підскоку кульки» представлена на рис. 5.

Порядок реалізації даного способу полягає в наступному: 
1 Прес-молот з гідропружним приводом «заряджають» до заданої величини тиску.

2 Установлюють кульку на торці штока гідропружного циліндра у спеціальній лунці.

3 «Вистрілюють» і заміряють висоту «підскоку кульки».

4 Розраховують величину потенційної енергії «підскоку кульки».

5 Перераховують величину енергії удару, яку накопичено в гідропружному циліндрі високошвидкісного прес-молота.

Розглянемо закономірності руху штока гідропружного циліндра при реалізації способу «підскоку кульки».

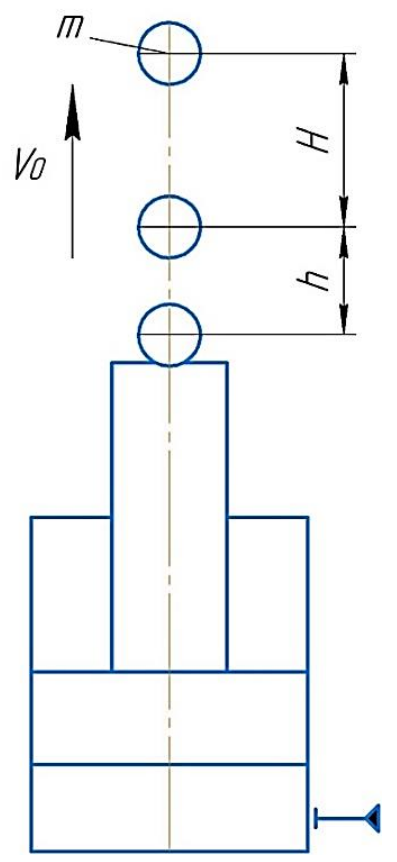

Рис. 5. Схема виміру енергії ударів способом «підскоку кульки»

Вважаємо, що до моменту висування штока на величину $h$, яка дорівнює амплітуді, швидкість рухомих частин гідропружного циліндра й кульки, установленої на торці штока $V_{0}$.

У верхній точці «підскоку кульки» кінетична енергія іiі руху дорівнює потенційній енергії підйому, а саме:

$$
W=m \cdot g \cdot H=m \cdot V_{0}^{2} / 2
$$

де $m$ - маса кульки;

$g$ - прискорення вільного падіння;

$H$ - висота «підскоку кульки», підкинутої вертикально вгору зі швидкістю $V_{0}$.

Переміщення штока гідропружного циліндра описується рівнянням

$$
x=h \cdot \cos (\omega \cdot t) \text {, }
$$

де $x$ - поточна координата переміщення штока;

$h$ - хід штока (амплітуда);

$\omega=\sqrt{C /(m+M)}-$ кутова частота коливань;

$C$ - жорсткість «гідравлічної пружини» гідропружного циліндра;

$M$ - маса рухомих частин гідропружного циліндра;

$t-$ час. 
При цьому рух кульки можна розглядати як рівномірно вповільнений з параметрами, пов'язаними залежністю:

$$
V_{0}=\sqrt{2 \cdot g \cdot H}
$$

Перша похідна від рівняння (2) має вигляд:

$$
\dot{x}=V_{0}=-h \cdot \omega \cdot \sin (\omega \cdot t) .
$$

При $\omega \cdot t=\frac{\pi}{2}$

$$
V_{0}=h \cdot \omega=h \cdot \sqrt{C /(m+M)} .
$$

Запишемо рівняння рівноваги:

$$
2 \cdot g \cdot H=h^{2} \cdot C /(m+M)=h^{2} \cdot C /(m \cdot(1+M / m)) .
$$

Звідки

$$
m \cdot g \cdot H=\left(C \cdot h^{2} / 2\right) \cdot(1 /(M / m+1)),
$$

де $C \cdot h^{2} / 2=W_{\text {екс }}-$ вимірювана енергія удару гідропружного циліндра.

Тоді рівняння (22) прийме вигляд:

$$
W_{\mathrm{e \kappa c}}=(m \cdot g \cdot H) \cdot(M / m+1),
$$

де $m \cdot g \cdot H$ - величина потенційної енергії, яку «запасає» кулька;

$M / m$ - відношення маси рухомих частин гідропружного циліндру до маси кульки.

Для перевірки адекватності запропонованої математичної моделі проведено експериментальні дослідження виміру енергії ударів гідропружного циліндра прес-молоті конструкції ДДМА. Параметри гідропружного циліндру прес-молота: обсяг робочої рідини, яка стискається $-Q=0,00257 \mathrm{~m}^{3}$, модуль об'ємної пружності робочої рідини $-E_{p}=1428,5 \mathrm{MПа,} \mathrm{ма-}$ са рухомих частин $-M=1,585 \kappa г$, маса кульки $-m=0,004$ кг.

У табл. 1 наведені розраховані та виміряні значення енергетичних параметрів високошвидкісного прес-молота з гідропружним приводом (конструкції ДДМА).

Таблиця 1

Розраховані та виміряні значення енергетичних параметрів високошвидкісного прес-молота конструкції ДДМА

\begin{tabular}{|c|c|c|c|c|}
\hline$p$, МПа & $W_{\text {теор }}$ Дж & $h$, м & $W_{\text {екс }}$ Дж & Похибка, \% \\
\hline 6 & 32,38 & 2,03 & 31,64 & 2,28 \\
\hline 7 & 44,08 & 2,78 & 43,30 & 1,77 \\
\hline 8 & 57,57 & 3,63 & 56,51 & 1,85 \\
\hline 9 & 72,86 & 4,76 & 74,12 & 1,73 \\
\hline 10 & 89,95 & 5,65 & 88,07 & 2,09 \\
\hline
\end{tabular}


Величина енергії, яку накопичено у гідропружному циліндрі прес-молота, розрахувалась за формулою [6]:

$$
W_{\text {теор }}=\Delta p^{2} \cdot Q /\left(2 \cdot E_{p}\right),
$$

де $\Delta p$ - робочий тиск у гідропружному циліндрі.

На рис. 6 представлені графіки $W_{\text {теор }}=f(p), W_{\text {екс }}=f(p)$.

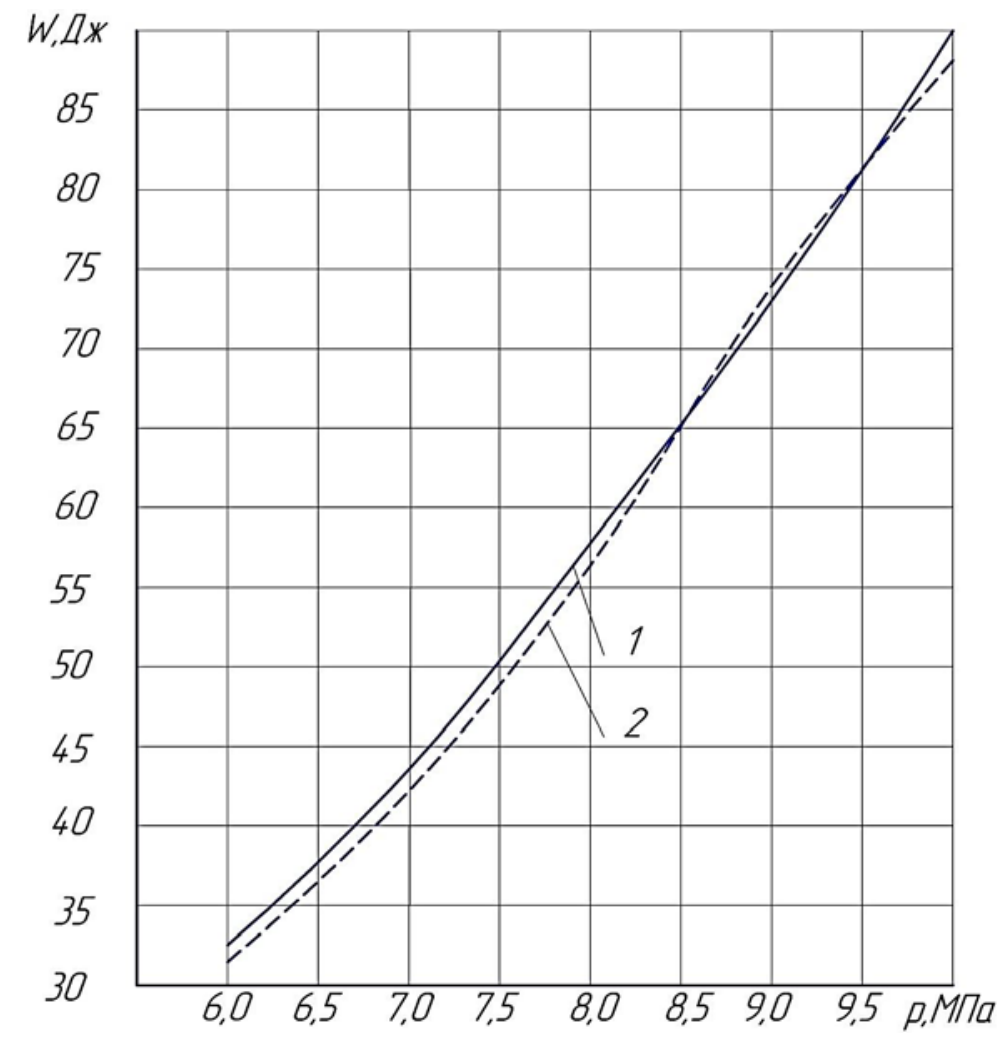

Рис. 6. Графіки $W=f(p): 1-W_{\text {теор }}=f(p) ; 2-W_{\text {екс }}=f(p)$

Аналіз результатів експериментальних даних дозволив зробити виводи про те, що похибка розрахованих і виміряних величин енергій удару прес-молоту конструкції ДДМА не перевищує 2,3 \%.

\section{ВИСНОВКИ}

1. Розроблено та досліджено спосіб вимірювання максимальної швидкості рухомих частин високошвидкісної машини з гідропружним приводом. Розбіжність значень теоретичної й виміряної максимальних швидкостей становить у середньому $18 \%$. Втрати швидкості рухомих частин прес-молота пов'язані більшою мірою із втратами на тертя штока в ущільненнях, дроселювання робочої рідини, а також із втратами енергії на розкриття імпульсного клапана гідропружного циліндра в момент формування переднього фронту ударної хвилі.

2. Розроблено та досліджено спосіб вимірювання енергії удару високошвидкісної машини з гідропружним приводом. Адекватність математичної моделі підтверджується експериментальними дослідженнями. Похибка розрахункових і виміряних величин енергії удару прес-молота (конструкції ДДМА) не перевищує 2,3 \%.

3. Запропоновані способи виміру енергетичних характеристик гідроприводу високошвидкісних машин можуть бути рекомендовані для впровадження на виробництві при дослідженні можливостей високошвидкісних машин і розробці пов'язаних з ними технологічних процесів. На відміну від відомих, запропоновані способи прості в реалізації, не вимагають 
наявності складного вимірювального устаткування, на похибку експерименту не впливають реальні умови ковальсько-пресового виробництва, зменшується час проведення експерименту й обсяг перерахувань.

\section{СПИСОК ВИКОРИСТАНОЇ ЛІТЕРАТУРИ}

1. Бочаров Ю. А. Кузнечно-штамповочное оборудование. Москва: Академия, 2008. 480 с.

2. Колотов Ю. В. Отечественные штамповочные молоты: состояние разработок и перспективы применения. Кузнечно-цтамповочное производство: Обработка материалов давлением. 2010, 2. С. 30-35.

3. Lahiri A. K. Production and Working of Metals and Alloys. Applied Metallurgy and Corrosion Control. 2017, pp. 41-77.

4. Sousa C., Silva E., Lopes M., Ramos A. The cutting stock problem: a case study in a manufacturer of pet vivaria. Operations Research and Big Data. 2015, pp. 221-228.

5. Truskovskii V. I., Sherkunov V. G. Shears for cutting rolled shapes and thick-walled tubes. Metallurgist. 2013. 56, pp. 848-853.

6. Роганов Л. Л. Совершенствование технологий и машин для разных отраслей машиностроения на основе развития гидроупругих и клиношарнирных механизмов. Обработка материалов давлением. Краматорск. ДГМА. 2011. 2 (27). С. 163-168.

7. Беккер Б. М., Заславский М. Л., Игнатенко Ю. Ф. Литье под давлением: учебник для вузов. Москва: Машиностроение, 1990. 400 с.

8. Chhabildas L. C., Davison L., Horie Y. High-pressure shock compression of solids. 8. Springer-Verlag Berlin- Heidelberg, 2005. ISBN 978-3-540-22866-0.

9. Gaol Ford Lumban, Shrivastava K., Akhtar J. Recent trends in physics of material science and technology. Singapore: Springer, 2015. DOI: ebook: 10.1007/978-981-287-128-2.

10. Lodygowski T., Rusiner A. Constitutive relations under impact loadings. Vienna: Springer, 2014. 285p. ISBN 978-3-7091-1768-2.

11. Карнаух С. Г. Совершенствование безотходных способов разделения сортового проката и оборудования для получения заготовок высокого качества: монография. Краматорск: ДГМА, 2010. 196 с.

\section{REFERENCES}

1. Bocharov Yu. A. Forging and stamping equipment. Moscow: Academy. 2008. 480 p. (in Russian).

2. Kolotov Yu.V. Domestic stamping hammers: state of development and application prospects. Forging and stamping production: Materials Working by Pressure. Moscow. 2010. 2, pp. 30-35. (in Russian).

3. Lahiri A.K. Production and Working of Metals and Alloys. Applied Metallurgy and Corrosion Control. 2017, pp. 41-77.

4. Sousa C., Silva E., Lopes M., Ramos A. The cutting stock problem: a case study in a manufacturer of pet vivaria. Operations Research and Big Data. 2015, pp. 221-228.

5. Truskovskii V. I., Sherkunov V. G. Shears for cutting rolled shapes and thick-walled tubes. Metallurgist. 2013. 56, pp. 848-853.

6. Roganov L.L. Improvement of technologies and machines for different branches of mechanical engineering based on the development of hydroelastic and clinoform mechanisms. Materials Working by Pressure. Kramatorsk. DSEA. 2011, 2 (27), pp. 163-168. (in Russian).

7. Becker B.M., Zaslavsky M.L., Ignatenko Yu.F. Casting under pressure: a textbook for universities. Moscow: Mechanical engineering. 1990. 400 p. (in Russian).

8. Chhabildas L.C., Davison L., Horie Y. High-pressure shock compression of solids. 8. Springer-Verlag Berlin- Heidelberg. 2005. ISBN 978-3-540-22866-0.

9. Gaol Ford Lumban, Shrivastava K., Akhtar J. Recent trends in physics of material science and technology. Singapore: Springer, 2015. DOI: ebook: 10.1007/978-981-287-128-2.

10. Lodygowski T., Rusiner A. Constitutive relations under impact loadings. Vienna: Springer, 2014. 285 p. ISBN 978-3-7091-1768-2.

11. Karnaukh S.G. Improvement of waste-free methods for separating long products and equipment for obtaining high quality billets: monograf. Kramatorsk: DSEA. 2010. 196 p. (in Russian).

Карнаух С. Г. - канд. техн. наук, доц., зав. каф. ОПМ ДДМА.

E-mail: k_sergii@i.ua; https://orcid.org/0000-0003-2878-4065

ДДМА - Донбаська державна машинобудівна академія, м. Краматорськ. 